\title{
Rapid histochemical staining method visualizing the role of Fusarium oxysporum catalase in xylem embolism formation and lupine wilt
}

\begin{abstract}
A simplest, rapid, reliable, and cost-effective staining method of the hypocotyls in the infected lupine plants was modified from Woodbury method for Native PAGE catalase to define the role of the fungal catalase produced by F. oxysporum on the reactive oxygen species (ROS) of Lupinus termis during infection. Fresh sections in hypocotyls of the infected plant and control ones were taken and stained directly on a glass slide. The visual detection of oxygen evolution from the xylem vessel, as a fungal catalase activity, gives a potential evidence for its role in embolism formation and wilt disease. White and blue color indicates the presence of catalase and $\mathrm{H}_{2} \mathrm{O}_{2}$ respectively. The catalase activity was significantly increased in the fungal growth medium than in the control plants. A model has built up to summarize the role of fungal catalase in the embolism formation, water current disconnection, and wilt disease.
\end{abstract}

Keywords: histochemical staining, embolism, Fusarium oxysporum, wilt, Lupinus termis, catalase, fungi
Volume 7 Issue 4 - 2019

\author{
RA Mohamed,' Heba Elsalahy, ${ }^{1,3}$ Osama A \\ Al-Bedak, ${ }^{2}$ \\ 'Botany and Microbiology Department, Faculty of Science, \\ Assiut University, Egypt \\ ${ }^{2}$ Assiut University Mycological Centre, Faculty of Science, Assiut \\ University, Egypt \\ ${ }^{3}$ Faculty of Life Sciences, Department of Agronomy and Crop \\ Science, Humboldt University of Berlin, Germany
}

Correspondence: Osama Abdel-Hafeez Mohamed Al-Bedak,
Assiut University Mycological Centre, Faculty of Science,Assiut
University,Assiut 7I5II, Egypt, Email osamaalbedak@gmail.com

Received: June 18, 2019| Published: July 05, 2019

\section{Introduction}

Fusarium wilt is a common vascular wilt disease caused by some species of Fusarium, of which Fusarium oxysporum is considered as the prime perpetrator of wilt disease. ${ }^{1}$ It classified, according to the host plant, into forma specialis and survives in a wide range of environments such as arctic, tropical, desert, cultivated and noncultivated soil, ${ }^{2}$ and spread by different ways such as water splash, planting equipment, transplanting of the infected plant and infected seeds). Fusarium oxysporum exhibits wide spectrum of pathogenicity against many hosts (ex. tomato, tobacco, lupine, cucurbits, sweet potatoes, and banana) at any stage of the plant life cycle. ${ }^{2}$ Fusarium oxysporum produces symptoms similar to that of Verticillium species (wilt, chlorosis, necrosis, premature leaf drop, discoloration of the vascular system, stunting, and damping-off).

Wilt is the most important one among all symptoms caused by this fungus. ${ }^{3}$ It produces microconidia, and chlamydospores and invades healthy plants using its mycelia or germinating spores through root tips or root wounds to reach the root cortex and xylem vessels, where it produces huge number of microconidia. ${ }^{2}$ Production of microconidia in a huge amount leads to sap stream blockage resulted in vascular system leading to cut-off of nutrient translocation. Finally, the plant transpiration becomes more than water transportation causing plant wilt. $^{2}$ Lupine is economically important worldwide agricultural crop includes many cultivars and widely used as a fodder, and its seeds have been used as a source of proteins replacing the animal and soybean origin in feed. It contains $33-40 \%$ of crude protein and 5-13 $\%$ oil. ${ }^{4,5}$ In Egypt, the productivity of 1482 ha cultivated with lupine is 2881 tons $(19,439 \mathrm{~kg} / \mathrm{ha}) .{ }^{6}$ The productivity of lupine remains low due to physiological, biological and environmental stress factors. However some scientists did their best to improve lupine quality and productivity. $^{7-10}$

\section{Fusarium oxysporum/Lupinus termis interaction}

The pathogen leads to enhancement of the reactive oxygen species (ROS) which is considered as oxidizing agents for many biomolecules such as proteins, lipids and nucleic acids, causing cell death. ${ }^{11-13}$ On the other hand, the plant defends itself against the pathogen by supporting the cell wall or suppresses the pathogen. ${ }^{14-16}$ Plant pathogens act to overcome the reactive oxygen species (ROS) of the host plant by upregulating extracellular catalases, which known as virulence factors in some microorganisms as Candida albicans and Agrobacterium tumefaciens. ${ }^{17,18}$ Previous studies demonstrated that, certain fungal infections caused lignifications of cortical walls which in turn allow the fungus to reach the stele ex: Gaeumannomyces graminis. ${ }^{19}$ However, this induced lignification did not provide effective resistance in the seedling stage. Neumann et al. (2006) supported the findings of Fellows ${ }^{20}$ with adding that water deficit was followed by inhibition of cell wall extensibility and decreasing of plant growth, specifically, in the elongation zone of maize roots.

Peng \& $\mathrm{Kuc}^{21}$ has provided a deeper insight regarding plant defense strategy, in susceptible cultivars, by reporting that the elevated levels of host cytotoxic hydrogen peroxide stops the exogenous fungal catalase as a defense mechanism. They also proved that the catalase infiltrates into the apoplastic space of the host cells breaking down $\mathrm{H}_{2} \mathrm{O}_{2}$ in the host pathogen interface. These integrated studies led to the consensus that a fungal enzyme ${ }^{22-26}$ suppresses the mechanical fortification of the cell wall. Hydrogen peroxide has a role in lignification process causing high cell wall rigidity. ${ }^{27,28} \mathrm{H}_{2} \mathrm{O}_{2}$ also mediates lignification, which minimizes the hydrolysis of plant cell walls of the control plant in grasses..$^{27}$ Besides, Mansoory et al. ${ }^{29}$ mentioned that Fusarium species produces its own catalase. The role of Fusarium catalase in embolism formation and wilt of lupine has not investigated yet. Therefore, in the present study, we modified the 
Woodbury et al. ${ }^{30}$ method for Native PAGE catalase for determination of the histopathology of catalase activity, in situ, and found out the relationship between the role of the fungal catalase produced by $F$. oxysporum against ROS of Lupinus termis during the infection and embolism generation inside the xylem vessels of the infected lupine.

\section{Materials and methods}

\section{Source of the pathogen and pathogenicity test}

Fusarium oxysporum AUMC 9272, responsible for wilt of $L$. termis ${ }^{31}$ was included in the current study. A 7-day-old culture of the pathogen grown on potato dextrose agar (PDA) with the composition of (g/l): potato infusion from 200g; dextrose, 20 and agar 15 (final $\mathrm{pH}$ at 5.6 \pm 0.2 ) and incubated at $28 \pm 2^{\circ} \mathrm{C}$, was used in the pathogenicity test under greenhouse conditions at $28 \pm 2^{\circ} \mathrm{C}$ for 15 days. The inoculum was prepared from 7-day-old culture of $F$. oxysporum AUMC 9272 in distilled water and the spore suspension was adjusted at $1 \times 10^{7}$ spore/ ml. $75 \mathrm{~g}$ barley, $25 \mathrm{~g}$ clean sand, $2 \mathrm{~g}$ sucrose, and $0.1 \mathrm{~g}$ yeast extract were mixed with $100 \mathrm{ml}$ spore suspension. Three replicate pots $(20 \mathrm{~cm}$ diameter \& $3 \mathrm{~kg}$ capacity) have inoculated with $5 \%(\mathrm{w} / \mathrm{w})$ of the inoculum, and three un-inoculated replicate pots have used as control. The pots have irrigated one week before planting of lupine. Seeds of Giza $\neq 1$ lupine cultivar was sterilized prior to planting using $0.1 \%$ sodium hypochlorite for $2 \mathrm{~min}$ then washed by sterile distilled water and then planted in the pots. ${ }^{31-33}$ After 40 days of planting, the infected and control plants were freshly harvested for estimation of catalase activity.

\section{Cutting preparation and staining}

Three replicates of 40-day-old of each of fresh healthy and infected plants have been used in the current investigation for, in situ estimation of catalase in different plant tissues, and determination its role in both defense mechanisms and pathogenicity. Cross sections were prepared from the hypocotyls using a rotary microtome (IHC World KD-1508A) according to the method of Mitra \& Loqué. ${ }^{34}$ The prepared sections were stained using adjusted native blue gel PAGE staining method of Woodbury et al., ${ }^{30}$ which has been modified in the current study to be direct method suitable for, in situ catalase activity staining in plant sections.

\section{Practical details}

The practical details of the current method are, discussed as follows:

1. Fresh sections $(10 \mu \mathrm{m}$ thick) of lupine hypocotyl were cut and were washed in $100 \mu$ l-distilled water. The step was repeated twice.

2. First, the sections were stained with Coomassie Brilliant Blue (R-250).

3. The hypocotyl sections were laid out on microscopic slides and covered with $50 \mu \mathrm{l}$ of $0.01 \% \mathrm{H}_{2} \mathrm{O}_{2}$ solution for $1 \mathrm{~min}$., and then the excess $\mathrm{H}_{2} \mathrm{O}_{2}$ solution was discarded.

4. The sections were then treated with $50 \mu 1$ of $0.5 \%$ solution of ferric chloride and then $50 \mu 1$ of $0.5 \%$ solution potassium and left to stand for $3 \mathrm{~min}$.

5. The reaction was stopped, immediately by the addition of $100 \mu \mathrm{l}$ of $1 \% \mathrm{HCl}(1 \mathrm{~min}$ each).

6. The prepared and stained sections then washed with distilled water, covered with $100 \mu 1$ of lacto-phenol cotton blue dye, fixed on glass slides, examined and photographed using Zeiss microscope (Model: Primo Star). Oxygen evolution in the form of air bubbles, indicates the catalase activity.

\section{Induction of catalase enzyme in the growth medium of F. oxysporum}

The catalase activity was determined in three replicates of 7-day-old culture of F. oxysporum AUMC 9272 grown at $25^{\circ} \mathrm{C}$ in Erlenmeyer conical flask containing $50 \mathrm{ml}$ potato dextrose broth (PDB) growth medium ( $\mathrm{pH}$ 6.5). The liquid culture of $F$. oxysporum AUMC 9272 has induced four times by $100 \mu 1$ of $33 \% \mathrm{H}_{2} \mathrm{O}_{2}$ for the $50 \mathrm{ml}$ PDB medium. The catalase induction was done from the $2^{\text {nd }}$ day to the $5^{\text {th }}$ day of incubation (once a day) under aseptic condition. For extraction of catalase enzyme, the mycelial growth of $F$. oxysporum, was homogenized, in a blender, with the broth medium (at 10000-rpm speed) and then centrifuged at $10000 \mathrm{xg}$ for $10 \mathrm{~min}$ at $4^{\circ} \mathrm{C}$. The cellfree supernatant has used as the source of catalase enzyme.

\section{Assay of catalase activity in lupine hypocotyls}

Three replicates $(0.5 \mathrm{~g}$ each) of lupine hypocotyl were frozen and ground in liquid nitrogen with mortar and pestle. Soluble proteins were extracted using the extraction buffer $[(50 \mathrm{mM}$ phosphate buffer; $\mathrm{pH}$ 7.0, 1mM EDTA, 1mM PMSF, $1 \%(\mathrm{w} / \mathrm{v})$ polyvinylpyrrolidone (PVP)]. The homogenized tissue was centrifuged at $10000 \mathrm{xg}$ for $20 \mathrm{~min}$ at $4^{\circ} \mathrm{C}$ and the supernatant was used for subsequent enzyme assays. Protein content was determined according to Bradford ${ }^{35}$ using bovine serum albumin (BSA) as standard. The reaction mixture (3ml) consisted of $300 \mu \mathrm{l}$ of the extracted enzyme, $50 \mathrm{mM}$ phosphate buffer $(\mathrm{pH} 7.0)$ and $10 \mathrm{mM}$ of $\mathrm{H}_{2} \mathrm{O}_{2}$. The absorbance at $240 \mathrm{~nm}$ at zero time $\left(\mathrm{t}_{0}\right)$ and after $3 \mathrm{~min}$ of reaction at room temperature $\left(\mathrm{t}_{3}\right)$ was measured and the catalase activity was expressed in $\mathrm{U} / \mathrm{mg}$ protein. Catalase activity was determined by the following consumption of $\mathrm{H}_{2} \mathrm{O}_{2}$ (extinction coefficient $39.4 \mathrm{mM}^{-1} \mathrm{~cm}^{-1}$ ) at $240 \mathrm{~nm}$ for $3 \mathrm{~min}^{36}$

\section{Statistical analysis}

One-way analysis of variance (ANOVA) was calculated for the control and treated plant to find out significance between mean values at $\mathrm{P}<0.05$ levels.

\section{Results}

According to the catalase pattern, the differences in color between the control and the infected plants confirmed that the plant tissues involved differently in the defense mechanism and catalase induction (Figures $1,3 \& 4$ ), and they also stained differently depending on catalase induction on them. It is clear that the epidermis, cortex, pith (Figure 1B, 1D, 1F respectively), and pericycle fiber (Figure 2B) showed very low densities of blue color in the infected plant indicating high induction of catalase. In contrast, the color intensity in xylem was lower than that in xylem fibers indicating low catalase induction. Moreover, Phloem and cambium (Figure 3B \& 3D) in the infected plant showed the lowest catalase activity. Noticeably, the special structure of companion cells in phloem and cambium cells almost did not show any color change under infection conditions.

Interestingly, catalase was notable in the pericycle fibers (Figure 2B) of the infected plant as a restricted light blue layer inside the lumen of each fiber element. The control plant tissues, including cortex parenchyma (Figure 1C), pith (Figure 1E), pericycle fibers and pith (Figure 2A), xylem vessels and xylem fibers (Figure 2C), showed bright interface layer in the apoplastic space, indicating high catalase activity in these positions compared with darker stain of the apoplastic 
space in most infected plant tissues, because of lower catalase activity in these positions. Interestingly, testing of the late stage of wilting (discolored xylem vessels) showed that the discolored area gave non-stained patches with Prussian blue (data not shown). In general, quantitative determination of the catalase in hypocotyls emphasized on significant increase of catalase activity under infection conditions by 3.45 -fold than that of the control plant (Figure 4; column 2). This increase may be attributed to the amount of induced catalase by the plant and the fungus itself. Furthermore, the fungal catalase in the medium filtrate was highly insignificant under infection conditions (1.3 fold) than in control plant (Figure 4; column 3). In this study, it has documented that an important evidence of oxygen evolution from xylem vessels of the infected plant (Figure 5B). This provided an opportunity to visualize the born of the moment of oxygen to form air bubbles.

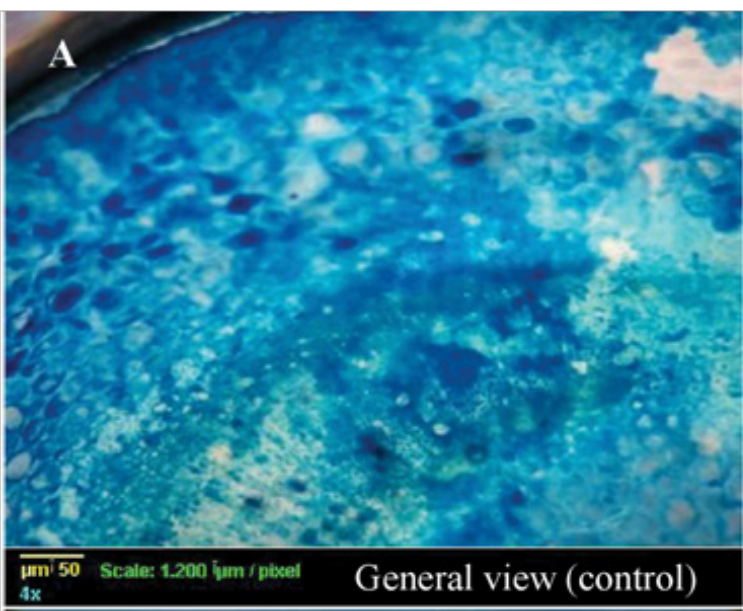

$\mathrm{C}$<smiles>CC(C)(Cl)Cl</smiles>
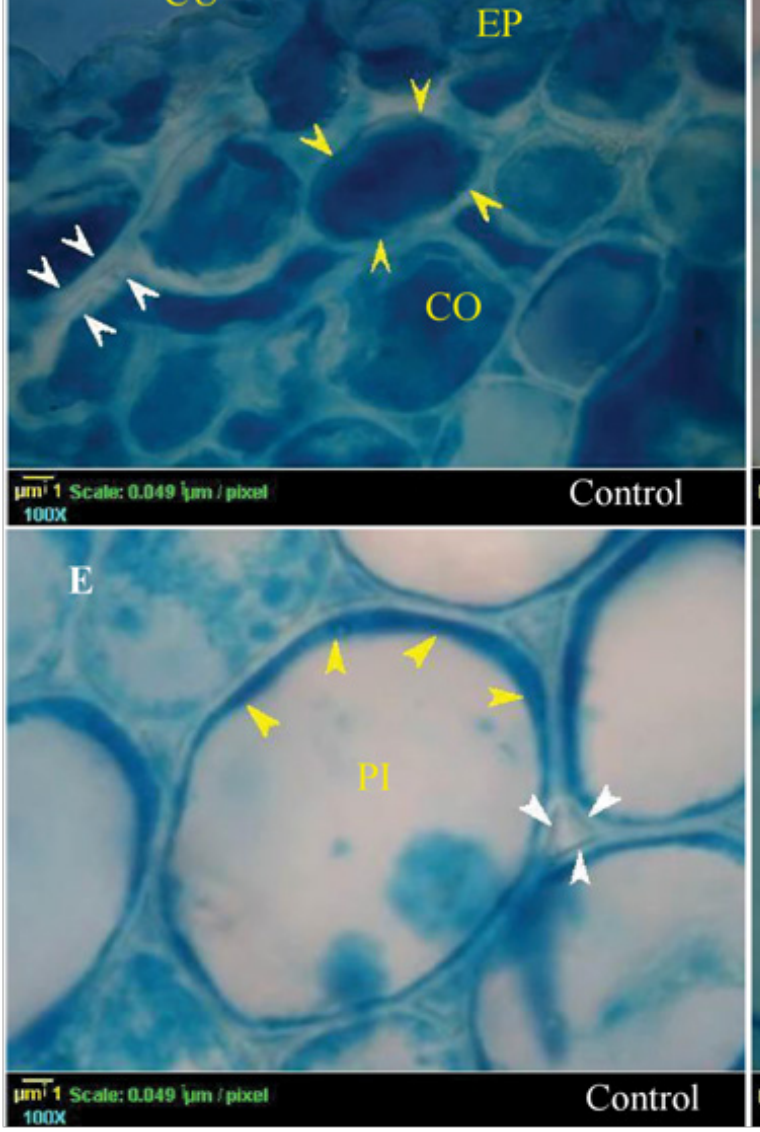
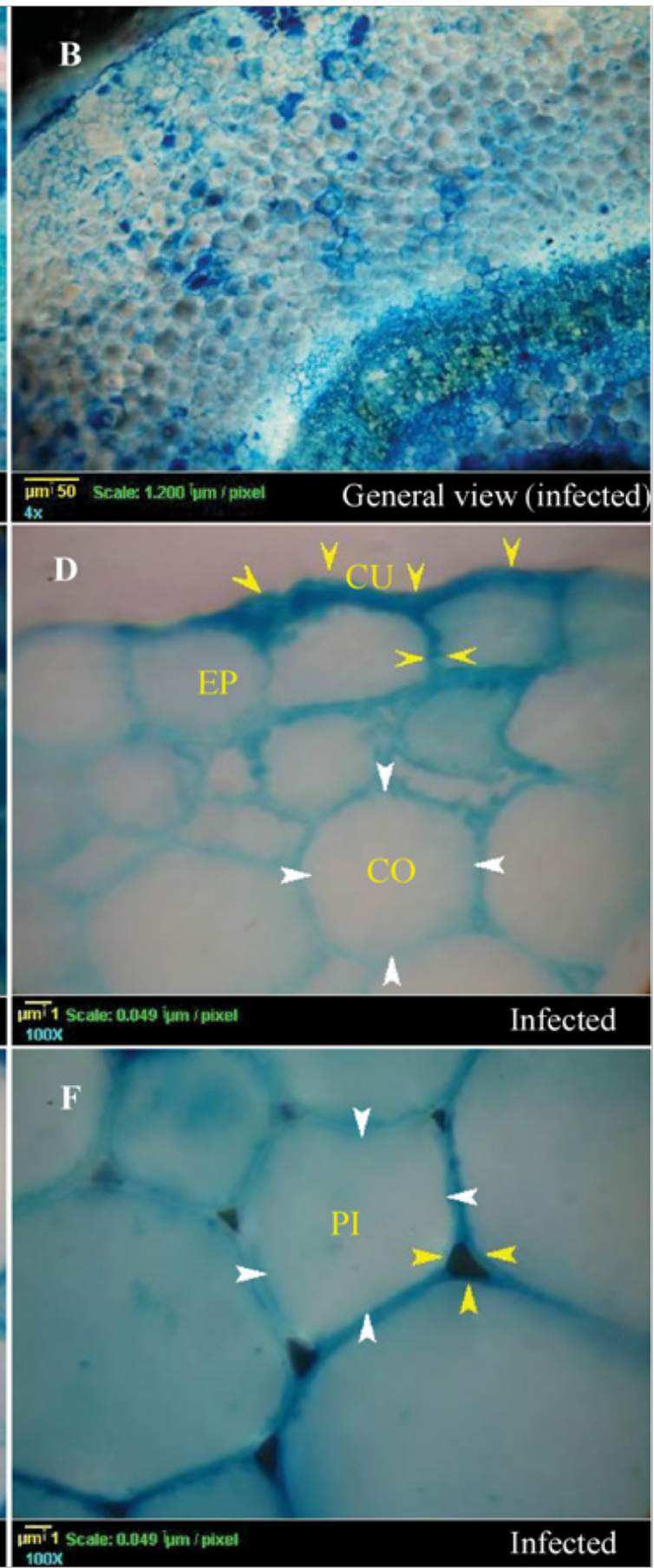

Figure I Histopathology of catalase (Transverse Section) by a modified technique of ferric ferrocyanide stain for detecting catalase induction on the cellular level on Lupinus termis tissues under infection by Fusarium oxysporum AUMC 9272. White arrows signalize the areas of light and bright blue color in both apoplast and cytosol (catalase containing places). Yellow arrows signalize the areas of dark blue color in both apoplast and cytosol (low catalase and high hydrogen peroxide). A, C and D represent sections of the control plant, while B, D, and F represent sections of the infected plant include general view, epidermal and cortical cells, the pith cells respectively. Abbreviations are epidermis (EP), cuticle (CU), cortex (CO), and pith (PI). 

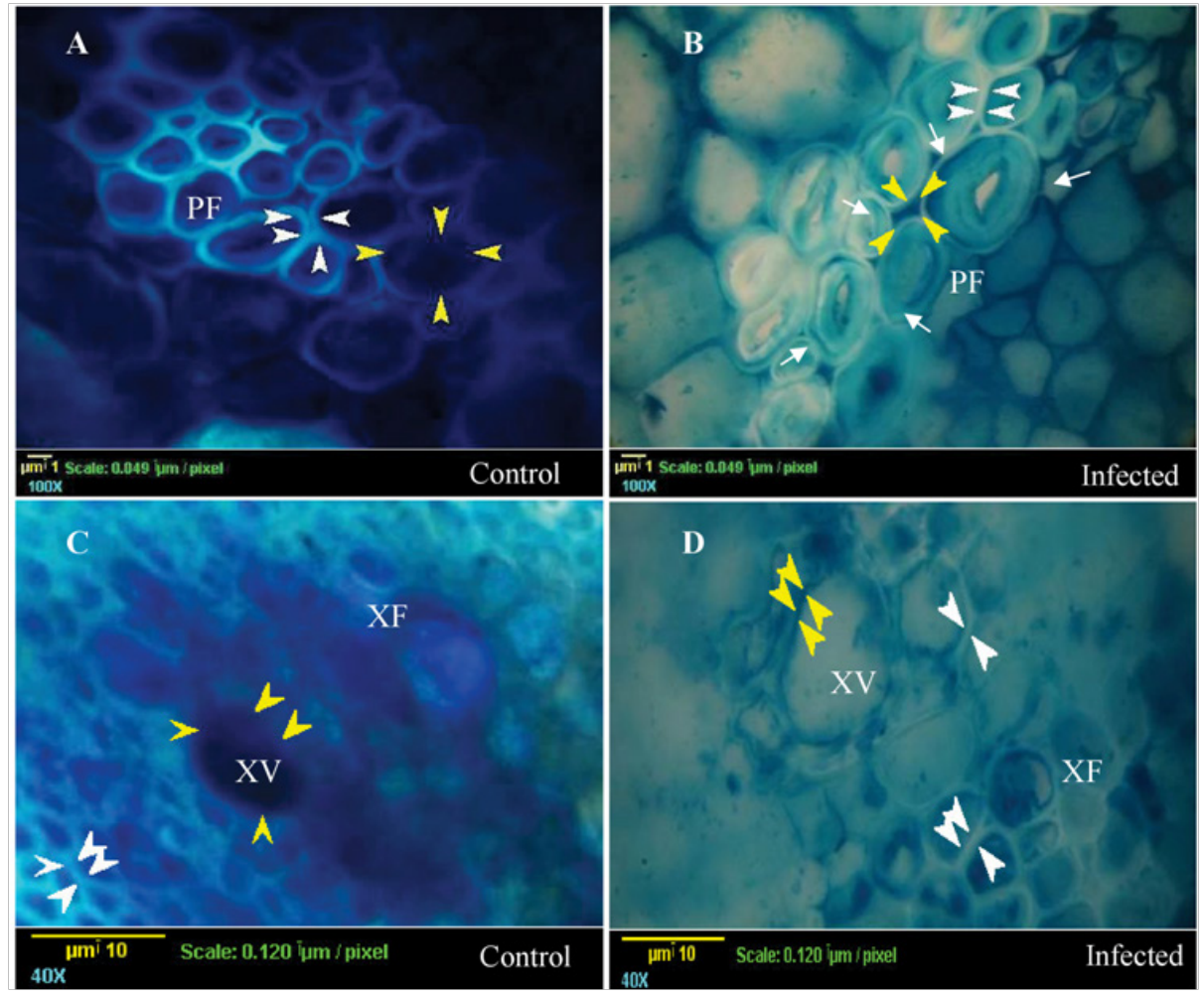

Figure 2 Histopathology of catalase in the lignified tissues (Transverse Section). A and C represents sections in the control plant, while B and D represent sections of the infected plant in the pericycle fiber and xylem vessels respectively. Abbreviations are pericycle fiber (PF), xylem vessels (XV), and xylem fiber (XF).White arrows refer to the areas of light and bright blue color, yellow arrows refer to the areas of dark blue color in both apoplast and element lumen.

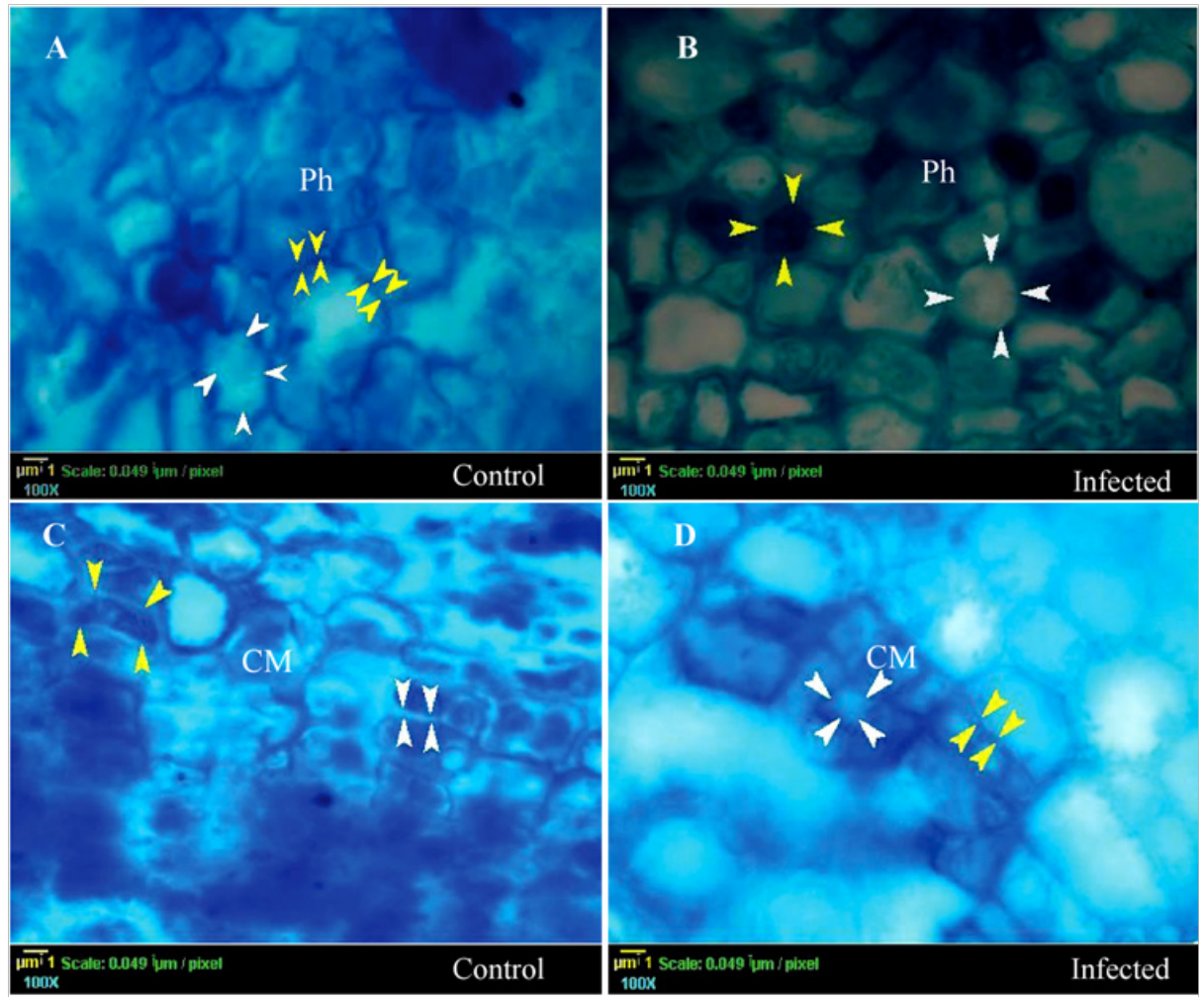

Figure 3 Histopathology of catalase of catalase in the phloem $(\mathrm{Ph})$ and cambium (CM) on Lupinus termis under infection conditions (Transverse Section). A, and $C$ represents the control plant; $B$ and $D$ represent the infected plant in the phloem and cambium respectively. White arrows show the high catalase activity places, while yellow arrows show the dark blue area with low catalase activity.l 


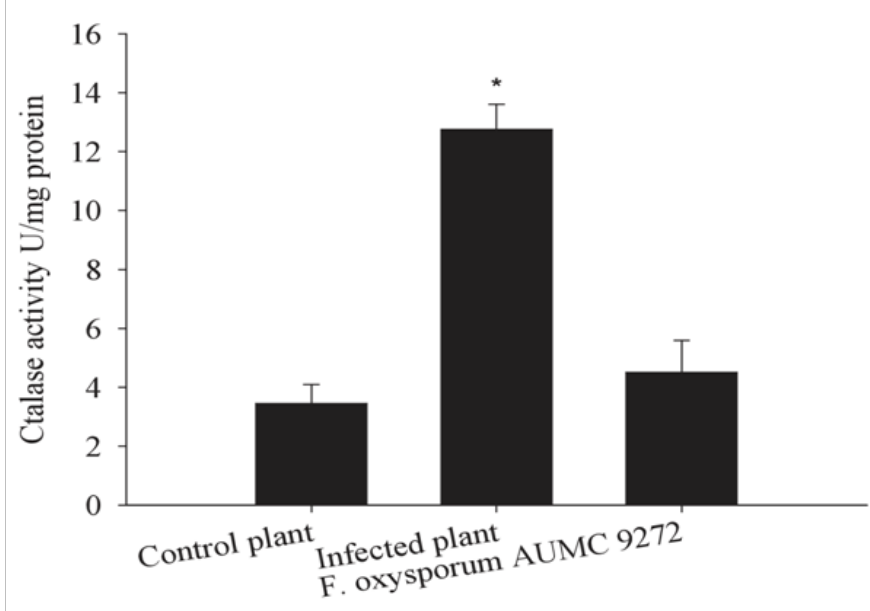

Figure 4 Total catalase activity extracted from hypocotyls of the plants $(\mathrm{U} / \mathrm{mg}$ protein) and fungal filtrate growth medium. Each column represents the mean of three replicate. T-test showed an insignificant difference at $\mathrm{P}<0.05$.
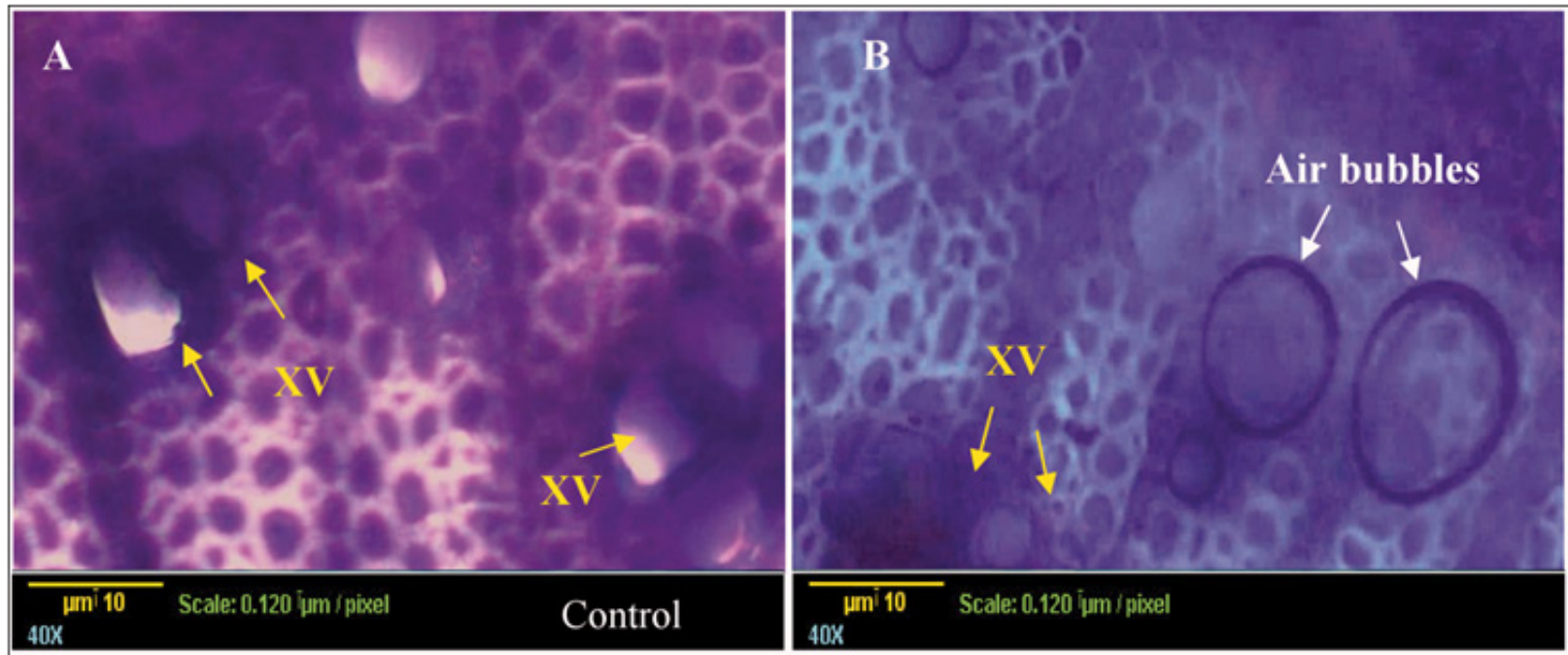

Figure 5 Oxygen evolution (air bubbles formation) after staining fresh cuttings with Coomassie Brilliant Blue (Transverse Section).A represents control plants with no air bubbles exit from xylem vessels and B, represents infected the plant with obvious and large air bubbles exit from xylem vessels (XV).

\section{Discussion}

The method developed by Woodbury et al. ${ }^{30}$ has been used for detection of catalase activity on the native polyacrylamide gel using the Prussian blue stain. In the current study, the modified method was used as an active stain for detection of catalase in the freshly prepared plant sections to determine the locations of the catalase induction caused by Fusarium wilt. The staining method was evaluated microscopically depending on the color degree of different plant tissues. The section of the infected plant was compared to that of the control plant under fixed experimental conditions. The stain reaction was chemically explained by reaction of localized hydrogen peroxide with potassium ferricyanide (III) which is reduced to the ferrocyanide (II) form. According to Perl's Prussian blue, Ferric chloride reacts with ferrocyanide (II) to form stable insoluble Prussian blue stain. The stain showed a range of Prussian blue color in the tissues depending on catalase activity. Hydrogen peroxide is oxidized to molecular oxygen in presences of active catalase and gave clear zone. The stain degree depends on the outcome of the reaction between catalase and hydrogen peroxide. Fusarium oxysporum AUMC 9272 has been tested for causing clear symptoms of wilt disease on Lupinus termis. ${ }^{31}$
The current technique aimed to evaluate the effect of fungal catalase produced by Fusarium oxysporum on Lupinus termis and its role in embolism formation. In general, the color intensity in each tissue was used as an indicator of catalase induction level, which was lighter in the infected plant than in the control one (Figure 1A \& 1B). Besides, the current method provides the scientists with a reliable and fast technique to diagnose the physiological plant responses to the fungal pathogen. This technique was suggested as a preliminary test for identifying the plant responses to the fungal pathogen.

\section{Advantages of the current method}

1. Up to date, the current method is the simplest, rapid, reliable, and cost-effective for histochemical staining of catalase activity compared with the method suggested by Bieglmayer $\& \mathrm{Graf}^{37}$ which takes very long time and much effort and used in the animal tissue only.

2. The changes of catalase in plant tissues can be monitored over short time intervals.

3. The role played by each plant tissue in defense mechanisms can be rapidly determined. 
4. It takes in consideration the catalase activity compared with the method of Schopfer ${ }^{38}$ which gave only a general view for the locality of $\mathrm{H}_{2} \mathrm{O}_{2}$ in the plant cell.

5. The current method also gives a strong evidence for the relation between embolism and the developed catalase in the xylem vessels.

Different plant tissues vary in their response to Fusarium wilt by the expression of different levels of catalase, which reduces the ROS to the safety level. Besides, catalase triggers the rapid conversion of hydrogen peroxide into biologically safe substances of $\mathrm{H}_{2} \mathrm{O}$ and $\mathrm{O}_{2}$.

\section{Strategy of dermal and ground tissues}

The highest response of catalase induction was regulated in parenchyma cells of the dermal and ground tissues (Figure 1D \& $1 \mathrm{~F})$ depending on the condition. This high response may be related to the vital functions of these tissues in plant protection. In control plant, a peripheral layer of the pith cells has a restricted dark zone that illustrated by the existence of higher amount of hydrogen peroxide (Figure 1E \& 1F). The apoplast zone of the control plant, in the epidermis, pith and cortex are clear. This could be attributed to two reasons, the first is the presence of catalase in the apoplastic fluid, and this was supported by the findings of Turhan et al. ${ }^{39}$ and the second is the direction of the plant energy towards the growth and expansion of its cells so that there are no need for more $\mathrm{H}_{2} \mathrm{O}_{2}$ production and exportation. However, the cytosol of the epidermis, cortex and pith cells of the infected plants showed extreme induction of the catalase in contrast to the control plant (Figure 1D \& 1F). The cuticle layer and the apoplast zone with blue color increased in the infected plant more than in the control plant (Figure 1C \& 1D). Because, these cells of these tissues, in the infected plant, try to export more $\mathrm{H}_{2} \mathrm{O}_{2}$ to increase the strength of the cell wall against the pathogen by enhancing the lignification process, this possibility is compatible with the results of Fellows. ${ }^{20} \mathrm{He}$ was reported that the lignification of the parenchyma cell (in cortex) might occur under pathogen attack to represent the first line of defense against pathogen invasion.

\section{Strategy of pericycle fibers}

The color degree revealed that the pericycle fiber showed a distinct response to the pathogen (Figure 2A). In the control plant, the pericycle fiber has a clear and visible color stratification. This layer was a dark blue, light blue and bright blue color in the zones of the fiber lumen, wall and the apoplast, respectively. Generally, the control plant is unstressed so that, the catalase enzyme is not induced and there is a high amount of $\mathrm{H}_{2} \mathrm{O}_{2}$, which needed for the lignification process in this fiber. Furthermore, Olson \& Varner ${ }^{25}$ introduced an evidence for up-regulating of the hydrogen peroxide in cells enhancing the lignification. Interestingly, in the infected plant, the overall view of the pericycle cell was lighter in color (Figure 2B). The lumen zone and the apoplastic layer of the fiber shifts to white color and the cell wall zone shift to blue green. The light colors of the fibers in the infected plant could be related to the fungal catalase which removes the hydrogen peroxide from this region and reduces the lignification process (Figure 2B).

\section{Strategy of the vascular tissues}

Vascular tissues (xylem and phloem) acted in a very interesting strategy against the pathogen (Fusarium oxysporum AUMC 9272). The xylem parenchyma (Figure 2D) and the phloem parenchyma (Figure 3B) have regulated the catalase level. The xylem and phloem, in the control plant, showed a very dark color in its vessel and their parenchyma (Figure 2C), this can be explained in the light of the Ros Barceló ${ }^{40}$ results. He reported that the xylem parenchyma (nonlignified tissues) is responsible for delivering $\mathrm{H}_{2} \mathrm{O}_{2}$ to the xylem vessels. The vascular tissue contains a high bulk of $\mathrm{H}_{2} \mathrm{O}_{2}$ which is required for lignification process of xylem vessels and fibers which gave rise to a strong signal of blue color without induction of catalase. Under stress conditions, the vascular tissue displayed a light blue color due to the lower bulk of $\mathrm{H}_{2} \mathrm{O}_{2}$ inside these vessels of infected tissue (Figure 2D \& Figure 3D). The vesicular vessel bulk differentiated into two main zones, white central cytosolic zone and peripheral blue zone which closed to the vessel wall. The white zone was a result of the presence of high amount of the fungal catalase which removes the hydrogen peroxide from the bulk. That leads to a reduction of the lignification process in the xylem vessel; mycelial growth mediation; keep the vessel wall week; production of oxygen for respiration inside the vessel; and finally, generating embolism. The outer cytosolic blue color in xylem vessel might be interpreted by a presence of low amount of $\mathrm{H}_{2} \mathrm{O}_{2}$ which is covered with a lower amount of the fungal catalase than the central zone. In later stages of the infection, the vessel becomes blocked by the fungus, reduction of the water transport, embolism generation, wilt and dwarf feature. This explanation is in accordance with Li \& Chapple, ${ }^{41}$ who demonstrated same explanation. Briefly, the strategy of the plant under infection conditions is to increase cell wall resistance against pathogen invasion through lignification process. This boosts cell wall rigidity and limits or reduces wall extensibility. In accordance with Neumann et al. (2006), the dark blue color in cells wall of the infected plant is a strong indicator for enhancing of the lignification process and reduction of the extensibility. Despite the plant lignification strategy used as a pathogen resistance mechanism, the fungus succeeds in reaching the vascular tissues. ${ }^{42}$

It was explained that this strategy might be followed under infection conditions ${ }^{43}$ which support the fungal catalase theory of the produced fungal catalase moves upward through xylem vessel to the stem and leaves. In the cambial cells of the control plant, the light blue borders of the apoplastic zone signalize the presence of high amount of the catalase enzyme (Figure 3C) and that interpretation is in accordance with Czaninski et al. ${ }^{44}$ In contrast, in the infected plants, the dark blue color in the cambial apoplastic zone is an indicator for the absence of the catalase enzymes (Figure 3D). That may limit the cell division rate, cell differentiation and/or cell expansion.

Quantitative estimation of the catalase activity in hypocotyls of the control plant, the wilted plant and in the PDB growth medium of the pathogen (Figure 4) supports the qualitative visualization with the chemical method and gave rise a real indicator for the induced amount of catalase under both conditions. Low amount of the catalase keeps the optimum condition for cell wall lignification and growth independent of stress conditions (Figure 4). In the infected plant, the output of the quantitative catalase is derived from both cytosolic catalase of the plant and the extracellular fungal catalase which getting in interruption of the biological pathways in the plant leading to the known wilt feature (Figure 4). The fungal catalase (Figure 4) induction supports the production of extracellular catalase inside the xylem vessels and its relationship to embolism. Sperry et al., ${ }^{45}$ and Skamnioti et al. ${ }^{43}$ reported that the xylem embolism in long trees was correlated to microbial growth in the vessel. Here, we correlate the embolism generation to the fungal catalase activity, not to the fungal growth. In addition, the wilt mainly did by the cut-off the upward water current by embolism and finally the wilting feature. 
Singh et al. ${ }^{46}$ reported that the upregulated proteins (six proteins) related to the oxidative stress response by the pathogen in the xylem vessel. Catalase peroxidase was the most upregulated protein among the proteins related to oxidative stress response. The catalase in the current study is similar in its role to the catalase of Aspergillus nidulans and catalase-peroxidase of Verticillium longisporum.

\section{Hypothesized model illustrates embolism formation and wilting}

This model, under infection conditions, summarizes the role of the fungal catalase in lignification suppression, in embolism formation and wilting symptoms. Fungal catalase dissociates the host derived
$\mathrm{H}_{2} \mathrm{O}_{2}$ into oxygen and water. Consequently, the released oxygen collected to form embolism which disconnects the water column (Figure $5 \& 6$ ). No one, before us, explained or proposed the relation of the fungal catalase to the mechanism of embolism formation. To sum up, fungal catalase is mainly directed toward the lignified tissue, especially xylem, to reduce the lignification process forming embolism and finally wilting symptoms. However, plant catalase is generally induced in the cytosol of the living cell to protect it against ROS under infection conditions. We expect that, the fungal catalase of the pathogen in the pen point of the fungal enzyme. It mediates the medium of the xylem sap for fungal growth, respiration, and protection. It was followed by other hydrolyzing enzymes.

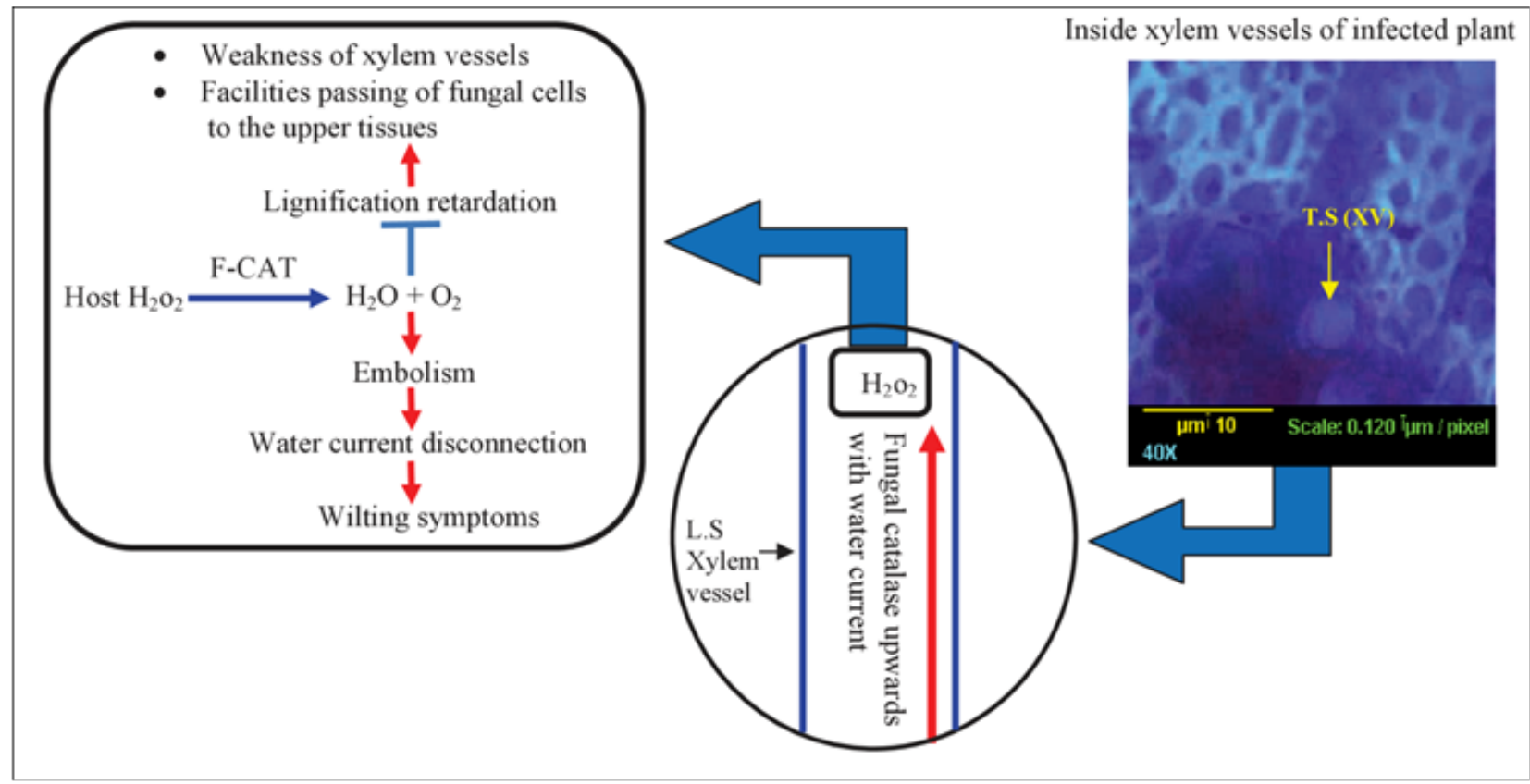

Figure 6 Hypothesized model for fungal catalase role in host xylem vessels describes the pathway of fungal catalase in the water current and its reaction with the $\mathrm{H}_{2} \mathrm{O} 2$. The final step of the model establishes an integrated equation for the ultimate effects of the fungal catalase (F-CAT) inside xylem vessels. Abbreviations: $T S$, transverse section; $L S$, longitudinal section; $X V$, xylem vessel.

\section{Conclusion}

The catalase enzyme, in the infected plant, was derived from both of the host plant and the fungal pathogen. The modified technique was to deliver the goal of this study and to show the participation of different plant tissues and fungal catalase in the interaction mechanism. Besides, the designed technique presents a dependable and fast method to identify the plant behavior on the cellular level for each specific tissue under attaching of Fusarium oxysporum; the interesting aspect of this study is the localization of the catalase enzyme which detected chemically by the modified method. The method provides a convincing evidence for the presence of a catalase in the xylem vessel during the fungal infection. The localized catalase, in these vessels, is expected to be a fungal catalase. This technique opens the door to understand deeply the role of the catalase of Fusarium oxysporum in the wilt disease and embolism formation. Furthermore, it allows us to visualize microscopically the evolution of the oxygen bubble by the action of fungal catalase on $\mathrm{H}_{2} \mathrm{O}_{2}$. We support the studying of the catalase of the fungal pathogen, typically as mentioned by Singh et al. ${ }^{46}$ Also; the catalase protects the fungal pathogen ${ }^{47}$ which attracted attention as potential virulence factors, ${ }^{48,49}$ and its importance in fungal development in the plant. ${ }^{50-52}$ Here, we highlight probable roles for fungal catalase in the ROS detoxification, oxygen generation in xylem vessels which is important for respiration, xylem sap mediation, embolism formation, water column disconnection and finally wilting of the host plant. ${ }^{53-60}$

\section{Acknowledgments}

Authors would like to acknowledge greatly Late Professor AH Moubasher, Professor of Mycology in Botany and Microbiology Department, Faculty of Science, Assiut University, and all the staff members at the Assiut University Mycological Centre (AUMC) for the provision of laboratory equipment.

\section{Authors' contribution}

R. A. Mohamed and H. Elsalahy are responsible for organizing the general idea, determination of catalase activity in the growth medium (BDP) of F. oxysporum and in the hypocotyls of both the infected and control plants. They shared the work of sectioning, staining, photographing, documenting and the manuscript writing. R. A. Mohamed and Osama A. Al-Bedak are responsible for the pathogenicity of lupine with $F$. oxysporum, and re-isolation of the pathogen from the infected plant after pathogenicity to confirm the success of pathogenicity. They also responsible for the manuscript writing and final production of the paper. 


\section{Conflicts of interest}

The authors declare no conflict of interest.

\section{References}

1. Snyder WC, Hansen HN. The species concept in Fusarium. American Journal of Botany. 1940;32(10):657-666.

2. George NA. Plant Pathology. 5th ed. Amsterdam: Elsevier Academic; 2005. 522 p.

3. Richter H. Pod rot of Lupinus caused by Fusarium. Mitteilungen aus der Biologischen Reichsanstalt. 1941;65:1-14.

4. Písaříková B, Zralý Z. Nutritional value of lupine in the diets for pigs (a review). Acta Vet Brno. 2009;78(3):399-409.

5. Khalid II, Elharadallou SB. Functional properties of cowpea (Vigna ungiculata L.Walp) and lupin (Lupinus termis) flour and protein isolates. J Nutr Food Sci. 2013;3:234

6. Agriculture Data FAO. Food and Agriculture Organization of United Nations; (2009).

7. Dawood MG, Taie HAA. Allelopathic potentiality of aqueous leaf extract of lantana and eucalyptus on germination, yield and chemical constituents of lupine seeds. J Biol Chem Environ Sci. 2009;4(4):167-185.

8. Ayad HS, Gamal El-Din KM. Effect of atonik and benzyladenine on growth and some biochemical constituents of lupine plant (Lupinus termis L.). American-Eurasian J Agric Environ Sci. 2011;10(4):519-524.

9. El-Saeid HM, Abouziena HF, Abd Alla MSA. Effect of some bioregulators on white lupine (Lupinus termis) seed yield and its components and on endogenous hormones content in seeds. Electronic Journal of Polish Agricultural Universities. 2011;14(4):1-7.

10. Amin AA, Awadi ME, Dawood MG, et al. Kinetin and Tryptophan Enhance Yield and Production Efficiency of Lupine (Lupinus Termis L.) Plants. World Rural Observations. 2014;6(4):50-56.

11. Lamb C, Dixon RA. The oxidative burst in plant disease resistance. Annu Rev Plant Physiol Plant Mol Biol. 1997;48:251-275.

12. Mayer AM, Staples RC, Gil-ad NL. Mechanisms of survival of necrotrophic fungal plant pathogens in hosts expressing the hypersensitive response. Phytochemistry. 2001;58(1):33-41.

13. Medentsev AG, Arinbasarova AI, Aimenko VK. Adaptation of the phytopathogenic fungus Fusarium decemcellulare to oxidative stress. Mikrobiologiia. 2001;70(1):34-38.

14. Apostol I, Heinstein PF, Low PS. Rapid stimulation of an oxidative burst during elicitation of cultured plant cells: Role in defense and signal transduction. Plant Physiol. 1989;90(1):109-116.

15. Hammond-Kosack KE, Jones JD. Resistance gene-dependent plan defense responses. Plant Cell. 1996;8(10):1773-1791.

16. van Loon LC, Rep M, Pieterse CMJ. Significance of inducible defenserelated proteins in infected plants. Annu Rev Phytopathol. 2006;44:135162 .

17. Wysong DR, Christin L, Sugar AM, et al. Cloning and sequencing of a Candida albicans catalase gene and effects of disruption of this gene. Infect Immun. 1998;66(5):1953-1961.

18. $\mathrm{Xu} X Q$, Pan SQ. An Agrobacterium catalase is a virulence factor involved in tumorigenesis. Mol Microbiol. 2000;35(2):407-414.

19. Kim KH, Willger SD, Park SW, et al. TmpL, a transmembrane protein required for intracellular redox homeostasis and virulence in a plant and an animal fungal pathogen. PLoS Pathog. 2009;5(11):e1000653.
20. Fellows H. Some chemical and morphological phenomena attending infection of the wheat plant by Ophiobolus grominis. J Agric Res. 1928;37(11):647-661.

21. Peng M, Kuc J. Peroxidase-generated hydrogen peroxide as a source of antifungal activity in vitro and on tobacco leaf disks. Phytopath. 1992;82:696-699.

22. Bradley DJ, Kjellbom P, Lamb CJ. Elicitor- and wound induced oxidative cross-linking of a proline-rich plant cell wall protein: A novel, rapid defense response. Cell. 1992;70(1):21-30.

23. Kohle H, Young DH, Kauss H. Physiological changes in suspensioncultured soybean cells elicited by treatment with chitosan. Plant Sci Lett. 1984;33(2):221-230.

24. Moerschbacher BM, Noll U, Gorrichon L, et al. Specific inhibition of lignification breaks hypersensitive resistance of wheat to stem rust. Plant Physiol. 1990;93(2):465-470.

25. Olson PD, Varner JE. Hydrogen peroxide and lignification. Plant J. 1993;4(5):887-892.

26. Sherwood RT, Vance CP. Resistance to fungal penetration in Gramineae. Phyto Pathol. 1980;70(4):273-279.

27. Carpita NC, Gibeaut DM. Structural models of primary cell walls in flowering plants: Consistency of molecular structure with the physical properties of the walls during growth. Plant J. 1993;3(1):1-30.

28. Grabber JH, Ralph J, Hatfield RD, et al. Dehydrogenation polymer-cell wall complexes as a model for lignified grass walls. J Agric Food Chem. 1996;44(6):1453-1459.

29. Mansoory D, Roozbahany NA, Mazinany H, et al. Chronic Fusarium Infection in an Adult Patient with Undiagnosed Chronic Granulomatous Disease. Clin Infect Dis. 2003;37(7):107-108.

30. Woodbury W, Spancer AK, Stahmann MA. An improved procedure using ferricyanide for detecting catalase isoenzymes. Anal Biochem. 1971;44(1):301-305.

31. Mohamed RA, Elsalahy HH, Al-Bedak OAH, et al. Reliable Analytic Strategy to Correlate the Morphological and Cytological Parameters on Lupinus termis L. against Fusarium oxysporum Infection. Journal of Agricultural Science and Technology. 2015;5:585-600.

32. Babay-Ahari AL, Toloui SL, Ghosta $\mathrm{Y}$, et al. Identification and pathogenicity of the fungi species causing root rot on pepper in West Azarbaijan Province. Iran international symposium root research and applications. International Symposium "RootRAP": Vienna, Austria; 2009.

33. Bhat RG, Smith RF, Koike ST, et al. Characterization of Verticillium dahlia isolates and wilt epidemic of pepper. Plant Dis. 2003;87(7):789 797.

34. Mitra PP, Loqué D. Histochemical staining of Arabidopsis thaliana secondary cell wall elements. Journal of visualized experiments: JoVE. 2014:87.

35. Bradford MM. Rapid and sensitive method for quantitation of microgram quantities of protein utilizing principle of protein-dye binding. Anal Biochem.1976;72:248-254.

36. Aebi H. Catalase. In: Methods of enzymatic analysis, HU Bergmayer, Ed. Academic Press: New York; 1974. 673-683p.

37. Bieglmayer C, Ruis H, Graf J. Cytochemical localization of catalase activity in glyoxysomes from castor bean endosperm. Plant Physiol. $1974 ; 53(2): 276-278$.

38. Schopfer P. Histochemical demonstration and localization of $\mathrm{H}_{2} \mathrm{O}_{2}$ in organs of higher plants by tissue printing on nitrocellulose paper. Plant Physiology. 1994;104(4):1269-1275. 
39. Turhan E, Aydogan C, Baykul A, et al. Apoplastic antioxidant enzymes in the leaves of two strawberry cultivars and their relationship to coldhardiness. Not Bot Hort Agrobot Cluj. 2012;40(2):114-122.

40. Ros Barceló A. Xylem parenchyma cells deliver the $\mathrm{H}_{2} \mathrm{O}_{2}$ necessary for lignification in differentiating xylem vessels. Planta. 2005;220(5):747756.

41. Li X, Chapple C. Understanding lignification: challenges beyond monolignol biosynthesis. Plant Physiol. 2010;154(2):449-452.

42. Vance CP, Kirk TK, Sherwood RT. Lignification as a mechanism of disease resistance. Ann Rev Phytopothol. 1980;18:259-288.

43. Czaninski Y, Sachot RM, Catesson AM. Cytochemical localization of hydrogen peroxide in lignified cell wall. Ann Bot. 1993;72(6):547-550.

44. Skamnioti $\mathrm{P}$, Henderson $\mathrm{C}$, Zhang $\mathrm{Z}$, et al. A novel role for catalase $\mathrm{B}$ in the maintenance of fungal cell-wall integrity during host invasion in the rice blast fungus Magnaporthe grisea. Mol Plant-Microbe Interact. 2007;20(5):568-580.

45. Sperry JS, Donnelly JR, Tyree MT. A method for measuring hydraulic conductivity and embolism in xylem. Plant, Cell \& Envir. 1988;11(1):3540 .

46. Singh S, Braus-Stromeyer SA, Timpner C, et al. The plant host Brassica napus induces in the pathogen Verticillium longisporum the expression of functional catalase peroxidase which is required for the late phase of disease. Molecular plant-microbe interactions. 2012;25(4):569-581.

47. Scherer M, Wei H, Liese R, et al. Aspergillus nidulans catalase peroxidase gene (cpeA) is transcriptionally induced during sexual development through the transcription factor StuA. Eukaryot Cell. 2002;1(5):725-735.

48. Garre V, Tenberge KB, Eising R. Secretion of a fungal extracellular catalase by Claviceps purpurea during infection of rye: Putative role in pathogenicity and suppression of host defense. Phytopathology. 1998;88(8):744-753.

49. Nathues E, Joshi S, Tenberge KB, et al. CPTF1, a CREB-like transcription factor, is involved in the oxidative stress response in the phytopathogen Claviceps purpurea and modulates ROS level in its host Secale cereale. Mol Plant-Microbe Interact. 2004;17(4):383-393.
50. Egan MJ, Wang ZY, Jones MA, et al. Generation of reactive oxygen species by fungal NADPH oxidases is required for rice blast disease. Proc Natl Acad Sci USA. 2007;104(28):11772-11777.

51. Nahlik K, Dumkow M, Bayram O, et al. The COP9 signalosome mediates transcriptional and metabolic response to hormones, oxidative stress protection and cell wall rearrangement during fungal development. Mol Microbiol. 2010;78(4):964-979.

52. Scott B, Eaton CJ. Role of reactive oxygen species in fungal cellular differentiations. Curr Opin Microbiol. 2008;11(6):488-493.

53. Abdel-Monaim MF, Abo-Elyousr KAM, Morsy KM. Effectiveness of plant extracts on suppression of damping-off and wilt diseases of lupine (Lupinus termis Forsik). Crop Prot. 2011;30(2):185-191.

54. Allen ON, Allen EK. The Leguminosae: A Source Book of Characteristics, Uses and Nodulation. Macmillan: London; 1981. 250 p.

55. Maknickiene Z. Effect of genotype on seed yield in lupine (Lupinus leteus L., Lupinus angustifolius L.) and resistance to fungal disease (Colletotrichtum lindemuthianuim Br. ET Cav., Fusarium oxysporum). Biologija. 2001;3:27-29.

56. Wojtaszek P. Oxidative burst: An early plant response to pathogen infection. Biochem J. 1997;322(Pt 3):681-692.

57. Chi MH, Park SY, Kim S, et al. A novel pathogenicity gene is required in the rice blast fungus to suppress the basal defenses of the host. PLoS Pathog. 2009;5(4):e1000401.

58. Huang K, Czymmek KJ, Caplan JL, et al. HYR1-mediated detoxification of reactive oxygen species is required for full virulence in the rice blast fungus. PLoS Pathog. 2011;7(4):e1001335.

59. Fan L, Linker R, Gepstein S, et al. Progressive inhibition by water deficit of cell wall extensibility and growth along the elongation zone of maize roots is related to increased lignin metabolism and progressive stelar accumulation of wall phenolics. Plant Physiol. 2006;140(2):603-612.

60. LeHir M, Herzog V, Fahimi HD. Cytochemical detection of catalase with 3, 3'-diaminobenzidine. Histochemistry. 1979;64(1):51-66. 